\title{
Spatial distribution and shell utilization in three sympatric hermit crabs at non-consolidated sublittoral of estuarine-bay complex in São Vicente, São Paulo, Brazil
}

\author{
Distribución del espacio y del uso de conchas por tres especies de cangrejo ermitaño en \\ el sublitoral no consolidado del complejo bahía-estuario de \\ São Vicente, São Paulo, Brasil \\ Bruno S. Sant'Anna ${ }^{1}$, Cilene M. Zangrande ${ }^{1}$, Álvaro L. D. Reigada ${ }^{1}$ and \\ Evandro Severino-Rodrigues ${ }^{2}$ \\ ${ }^{1}$ Universidade Estadual Paulista, Campus do Litoral Paulista, Unidade São Vicente \\ Grupo de Pesquisa em Biologia de Crustáceos (CRUSTA) \\ Pça. Infante Dom Henrique, s/n. - CEP 11330-900 - São Vicente (SP), Brasil \\ ${ }^{2}$ Centro Avançado de Pesquisa Tecnológica do Agronegócio do Pescado Marinho, Instituto de Pesca \\ APTA, SAA. Av. Bartolomeu de Gusmão, 192, CEP 11030-906, Santos (SP), Brasil \\ areigada@uol.com.br
}

Resumen.- El objetivo de este estudio fue definir la distribución de tres especies de cangrejo ermitaño y la utilización de conchas en el sublitoral no consolidado del complejo bahía-estuario de São Vicente, Provincia de São Paulo, en Brasil. Las muestras fueron retiradas mensualmente durante dos años consecutivos. Factores ambientales como temperatura, salinidad y profundidad, también fueron registrados todos los meses. Las tres especies de ermitaños Clibanarius vittatus, Loxopagurus loxochelis e Isocheles sawayai fueron capturadas con la utilización de la concha de seis especies de gasterópodos; 92,7\% de los individuos utilizaron conchas de Stramonita haemastoma. Los resultados indicaron una fuerte asociación entre la distribución espacial de los ermitaños y la salinidad, que mostró ser el principal factor límite de su distribución en ese estuario. I. sawayai fue la única especie presente en todos los lugares muestreados en este estudio; $C$. vittatus fue capturado solamente en los lugares de menor salinidad y L. loxochelis estaba presente sólo donde la salinidad se mantuvo con altos niveles.

Palabras clave: Clibanarius, Loxopaguros, Isocheles, Anomura

\begin{abstract}
The objective of the present study was to characterize the spatial distribution and shell utilization of three hermit crab species in the estuarine-bay complex of São Vicente, São Paulo State, Brazil. Monthly samples were done throughout two years, in the non-consolidated sub-littoral at the estuarine-bay complex. The environmental factors, such as temperature, salinity and depth, were measured every month. The three hermit crab species, Clibanarius vittatus, Loxopagurus loxochelis and Isocheles sawayai, were captured utilizing shells from six gastropods species; $92.7 \%$ of the hermit crabs utilized Stramonita haemastoma. The results suggest a strong correlation between hermit crabs spatial distribution and salinity, which was considered the main environmental factor limiting their distribution in the estuary. I. sawayai was the only species present in all transects sampled; C. vittatus was captured only in regions with low salinity and $L$. loxochelis occurred only in high salinity waters.
\end{abstract}

Key words: Clibanarius, Loxopaguros, Isocheles, Anomura

\section{Introduction}

To characterize the spatial distribution of any species is necessary to search information about the animal biological aspects, such as the way of feeding and behavior. However, it is also necessary to analyze the local characteristics to evaluate the geological history and the environmental factors' variations (FernandesGóes 1997).

Abiotic factors must be carefully considered because some ecological interactions are the main cause of 
seasonal and spatial distribution of individuals (Buchanan \& Stoner 1988). There are many studies confirming the influence of interactions among abiotic factors. One of them is Fransozo et al. (1992) study, which associated the brachyurans' distribution to organic matter rate, where some species only occurred in places of higher indices of organic matter; in Ubatuba bay, Southeast of Brazil, Negreiros-Fransozo et al. (1997) found the same correlation with anomurans in this location. Although the influence of organic matter in the crustaceans distribution verified in the studies above, it is important to stand out that in most cases there are several factors that determine the occurrence and distribution of benthic organisms, as verified by Fernandez-Góes (2000) who studied an anomuran community in the Southeast of Brazil.

Despite of the great importance of the environmental conditions to the anomurans distribution, mainly in hermit crab populations, it should also be considered the biogenetic factor and the shell availability (NegreirosFransozo et al. 1997), because of its dependence of bigger shells throughout its life for survival. Hermit crabs are dependent of the gastropod shells, and this fact, according to Reese (1969), is the main adaptation of this group, allowing its dominance of the intertidal region.

In the lack of gastropod shells, hermit crabs have been recorded using bottle caps, bamboo pieces (Imafuku \& Ando 1999) and even shells of land gastropods (Meireles \& Mantelatto 2003, Sant'Anna et al. 2005). The shell is a so important resource that the use of other structures or shells with the invert spiral, can deform the hermit crab abdomen (Blackstone 1985), and in a similar way, inadequate shells can delay the crab growth (Osorno et al. 1998) and reproduction (Bertness 1981).

The aim of the present study was to characterize the spatial distribution and shell utilization by the three hermit crab species: Clibanarius vittatus (Bosc, 1802), Loxopagurus loxochelis (Moreira, 1901) and Isocheles sawayai Forest \& Saint Laurent, 1967 in the bay-estuary complex of São Vicente, São Paulo, Brazil.

\section{Material and methods}

The hermit crab specimens were monthly captured in São Vicente (SP) from September 2000 to August 2002. A shrimp fishing boat equipped with an otter-trawl net (length: $7.5 \mathrm{~m}$; aperture: $3.7 \mathrm{~m}$ and height: $2.0 \mathrm{~m}$ ) with $10 \mathrm{~mm}$ mesh size was used to capture the animals during a 20-min sampling at four transects: Transect 1 (T1): Itararé beach, between Porchat and Urubuqueçaba islands; Transect 2 (T2): in front of Paranapuã beach, behind of Porchat island; Transect 3 (T3): São Vicente square, between Pênsil and Mar Pequeno bridges and Transect 4 (T4): São Vicente square, between Mar Pequeno and Barreiros bridges (Fig. 1).

Hermit crabs were sorted from other fishery products and identified according to Melo (1999), and the gastropods shells, according to Rios (1994).

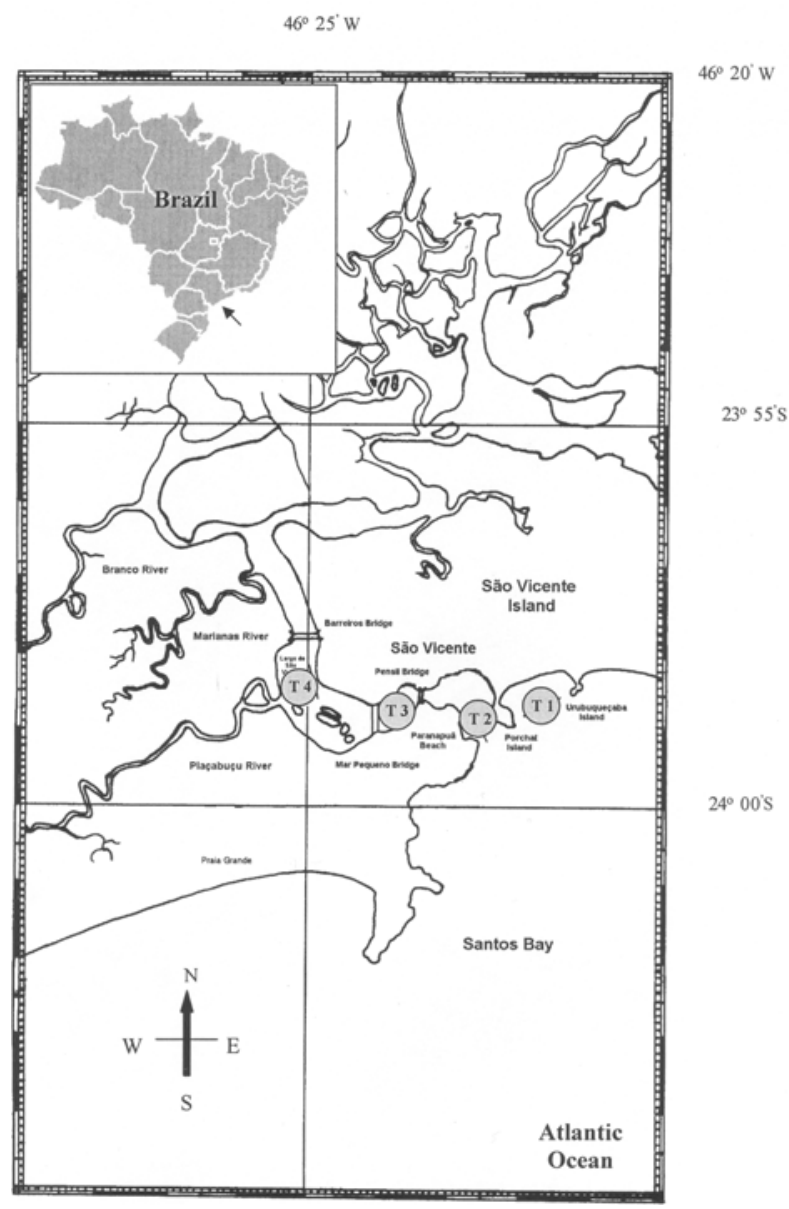

Figure 1

Studied area in the bay-estuary complex of São Vicente, São Paulo, Brazil. Transects:T1, T2,T3 and T4

Área de estudio en el complejo estuario-bahía de São Vicente, São Paulo, Brasil. Transectas: T1, T2, T3 y T4 
The water was monthly sampled with a Nansen bottle. The water temperature and salinity were measured using a graduated thermometer $\left(1^{\circ} \mathrm{C}\right)$ and a refractometer, respectively; the depth (m) was registered using a tapeline.

Environmental factors data were tested by a one-way ANOVA to identify statistical differences among transects. Environmental data were associated with hermit crab spatial distribution and tested by Pearson Linear Correlation Analysis $(P<0.05)$ to determine the influence of each abiotic factor, according to Sokal \& Rohlf (1995).

\section{Results}

Three hermit crab species composing 166 individuals were captured; 39 Clibanarius vittatus (Bosc, 1802), 19 Loxopagurus loxochelis (Moreira, 1901) and 108 Isocheles sawayai (Forest \& Saint Laurent, 1967) were registered, utilizing shells of six gastropods species. More than $92 \%$ of the collected individuals were associated to Stramonita haemastoma (Linnaeus, 1767) shells. The other gastropods shells used by hermit crabs are presented in Table 1.

Isocheles sawayai showed high abundance when compared to other hermit crab species, and it was present along all transects sampled. $C$. vittatus was not found in transect 1 and L. loxochelis was collected in transects 1 and 2 (Fig. 2).
Temperature $\left({ }^{\circ} \mathrm{C}\right)$, salinity (psu) and depth (m) data are presented in Table 2. Statistical differences from environmental data among transects was verified for salinity $(F=16.88, P<0.01)$, which varied from 15 to 36 psu and depth $(F=15.38, P<0.05)$, from 2 to $6 \mathrm{~m}$. The Pearson Correlation between abiotic factors and hermit crabs distribution showed a positive correlation between salinity and abundance of $C$. vittatus (in T3; $r=0.48$, $P=0.01$ and $\mathrm{T} 4, r=0.46, P=0.02$ ) and $L$. loxochelis (in $\mathrm{T} 1 ; r=0.50, P=0.01)$.

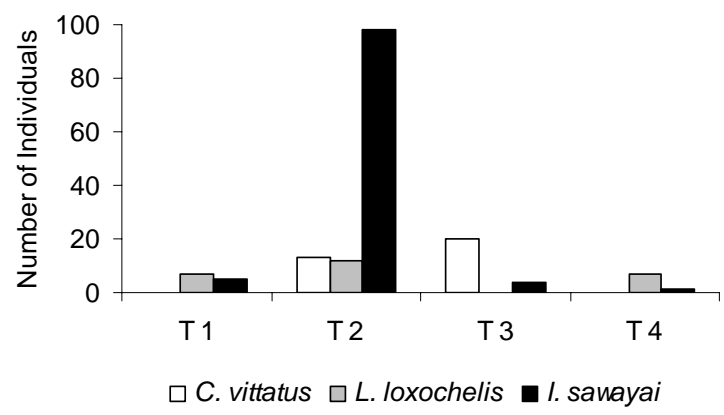

Figure 2

Distribution of hermit crabs at São Vicente estuary-bay complex, Brazil. T: transect

Distribución de cangrejos ermitaños en el complejo bahíaestuario de São Vicente, Brasil. T: transecta

Table 1

Gastropod shells species used by hermit crabs at São Vicente estuarine-bay complex, Brazil

Conchas de gasterópodos utilizadas por cangrejos ermitaño en el complejo bahía-estuario de São Vicente, Brasil

\begin{tabular}{lccccc}
\hline \multicolumn{1}{c}{ Gastropod species } & C. vittatus & I. sawayai & L. loxocheles & \multicolumn{2}{c}{ Total (N / \%) } \\
\hline Stramonita haemastoma & 39 & 99 & 16 & 154 & 92.77 \\
Buccinanops gradatum & - & - & 1 & 1 & 0.60 \\
Olivancillaria urceus & - & 1 & 2 & 3 & 1.81 \\
Cymatium parthenopeum & - & 3 & - & 3 & 1.81 \\
Nassarius vibex & - & 3 & - & 3 & 1.81 \\
Tegula viridula & - & 2 & - & 2 & 1.20 \\
Total & 39 & 108 & 19 & 166 & 100 \\
\hline
\end{tabular}


Table 2

Environmental data (mean \pm standard deviation) registered at four sampled transects in São Vicente estuarine-bay complex, Brazil

Datos ambientales (promedio \pm desviación estándar) registrados en cuatro transectas de muestreo en el complejo bahía-estuario en São Vicente, Brasil

\begin{tabular}{|c|c|c|c|c|c|c|}
\hline & \multicolumn{2}{|c|}{ Temperature $\left({ }^{\circ} \mathrm{C}\right)$} & \multicolumn{2}{|c|}{ Salinity (psu) } & \multicolumn{2}{|c|}{ Depth (m) } \\
\hline Transect & & & & $\bar{X} \pm \mathrm{s}$ & & $\pm \mathrm{s}$ \\
\hline 1 & 24.13 & 3.21 & 33.58 & 1.91 & 5.29 & 0.68 \\
\hline 2 & 24.24 & 3.30 & 32.36 & 2.63 & 3.96 & 1.02 \\
\hline 3 & 24.49 & 3.16 & 29.61 & 4.42 & 4.00 & 1.04 \\
\hline 4 & 24.69 & 3.02 & 27.38 & 3.50 & 5.92 & 1.75 \\
\hline Total & 24.38 & 3.20 & 30.73 & 4.07 & 4.79 & 1.46 \\
\hline
\end{tabular}

\section{Discussion}

According to Vernberg \& Vernberg (1970), the spatial distribution of marine organisms is determined by environmental factors interactions. In estuarine areas, the gradient of salinity is the main limiting factor to the distribution of the crustaceans (Taissoun 1969, Abreu 1980, Zangrande et al. 2003). The portunid Arenaeus cribrarius (Lamarck, 1818) represents a typical example for the relationship between the spatial distribution and environmental factors variation (Pinheiro et al. 1996). According to Pita et al. (1985) and Zangrande et al. (2003), the water salinity was a limiting factor for this Portunidae species, which occurs only in regions with high-salinity water, while for the hermit crab $L$. loxochelis distribution, the very fine sand fraction was the most important abiotic factor (Bertini et al. 2004).

The hermit crab L. loxochelis, studied by Mantelatto et al. (2004), showed an association between the spatialtemporal distribution and high depth, fine sand and high values of organic matter in sediment. In the present study, the distribution of $L$. loxochelis was associated to high-salinity water, a different pattern from that observed by Santos et al. (2000), who collected this hermit crab species in an estuarine region.

According to Melo (1999), C. vittatus is found from Occidental Atlantic (east of USA) to Southern Brazil (Santa Catarina), living in estuarine regions, coral reefs and in sand's bottom in low waters (up to $22 \mathrm{~m}$ of depth). In São Vicente Estuary, this hermit crab species showed a large distribution and was not present only in the transect 1 . The highest abundances occurred in regions with low salinity.

The hermit crab Isocheles sawayai shows tolerance to low salinity and usually occurs in regions influenced by freshwater (Negreiros-Fransozo et al. 1997). In the present study, the same situation was verified, due to the presence of this hermit crab in all transects. According to the observed pattern of this hermit crab distribution, it is possible to conclude that salinity is the main factor limiting $L$. loxochelis and $C$. vittatus spatial distribution, but not for I. sawayai.

The utilization of gastropod shells by hermit crabs is a result of several interactions, which involve competition among these crustacean communities to the resource of available shell, adequate for its occupation. The shell availability is an important factor (NegreirosFransozo et al. 1991), which in many situations may indicate a high abundance of gastropod species in the region (Pinheiro et al. 1993, Reigada \& Santos 1997).

According to Reigada \& Santos (1997), who studied the biology and shell utilization of $C$. vittatus in the intertidal region of Bay-Estuary Complex of São Vicente, there is a high occupation of S. haemastoma shells, and in the present study the same pattern was observed. Moreover, in laboratory tests, Turra \& Fosca (2002) observed that $C$. vittatus preferentially utilized shells of $S$. haemastoma, different of the pattern found in environmental observations of the same study. In the 
first study the shell aperture was related to the hermit crab size, Pinheiro et al. (1993) also observed that $I$. sawayai utilized gastropod shells preferentially of the species more available in the region, S. haemastoma, in the same way that $C$. vittatus in the Reigada \& Santos (1997) study. Martinelli (1998), studying a L. loxochelis population, found that the shells of the most available gastropods were occupied for this hermit crab, being respectively Olivancillaria urceus (Röding, 1798) and Buccinanops gradatum (Deshayes, 1844). The results of Peres (2005), corroborated with Martinelli (1998), where a population of $L$. loxochelis in a close region, utilized the same shell resources. The gastropod $S$. haemastoma, the most utilized species by hermit crabs in the present study, is common and abundant in the rocky shore near the sampled locality, and consequently it corresponds to the great part of shell availability for hermit crab populations.

Finally, the salinity seems to be the main abiotic factor limiting the distribution of the three sympatric anomurans species in São Vicente Estuarine-Bay Complex and the shell utilization may reflect the most abundant gastropod species in the region.

\section{Acknowledgments}

We are thankful to FAPESP (\# 00/06505-7), for the fellowship to the third author. Also thanks to the Biol. Carlos Magenta Cunha for the gastropods shells identification. We would like to thank MSc. Gustavo Yomar Hattori for translating the manuscript, and to the referees, for their valuable commentaries and suggestions.

\section{Literatura citada}

Abreu J. 1980. Distribuição e ecologia dos Decapoda numa área estuarina de Ubatuba (SP). Boletim do Instituto Oceanográfico 29(2): 1-3.

Bertini G, A Fransozo \& AA Braga. 2004. Ecological distribution and reproductive period of the hermit crab Loxopagurus loxochelis (Anomura, Diogenidae) on the northern coast of Sao Paulo State, Brazil. Journal of Natural History 38(18): 2331-2344.

Bertness MD. 1981. The influence of shell type on hermit crab growth rate and clutch size (Decapoda, Anomura). Crustaceana 40: 197-205.
Blackstone NW. 1985. The effects of shell size and shape on growth and form in the hermit crab Pagurus longicarpus. Bulletin of Biology 168: 75-90.

Buchanan BA \& AW Stoner. 1988. Distributional patterns of blue crabs (Callinectes sp.) in a tropical estuarine lagoon. Estuaries 11(4): 231-239.

Fernandes-Góes LC. 1997. Distribuição e biologia populacional de Dardanus insignis (Saussure, 1858) (Crustacea: Decapoda: Anomura) Na região de Ubatuba, SP. M Sc Thesis, Universidade Estadual Paulista, São Paulo, 150 pp.

Fernandes-Góes LC. 2000. Diversidade e bioecologia das comunidades de anomuros (Crustacea, Decapoda) do substrato não consolidado da região de Ubatuba, SP. Ph D Thesis, Universidade Estadual Paulista, São Paulo, 133 pp.

Fransozo A, ML Negreiros-Fransozo, FLM Mantelatto, MAA Pinheiro \& S Santos. 1992. Composição e distribuição dos Brachyura (Crustacea, Decapoda) no sublitoral não consolidado na Enseada da Fortaleza, Ubatuba (SP). Revista Brasileira de Biologia 52(4): 667675.

Imafuku M \& T Ando. 1999. Behaviour and morphology of pagurid hermit crabs (Decapoda, Anomura) that live in tusk shells (Mollusca, Scaphopoda). Crustaceana 72(2): 129-144.

Mantelatto FLM, JM Martinelli \& A Fransozo. 2004. Temporal-spatial distribution of the hermit crab Loxopagurus loxochelis (Decapoda: Diogenidae) from Ubatuba Bay, São Paulo State, Brazil. Revista de Biologia Tropical 52(1): 47-55.

Martinelli JM. 1998. Estrutura populacional, distribuição espaço-temporal e crescimento relativo do ermitão Loxopagurus loxochelis (Moreira, 1901) na Região de Ubatuba, Litoral Norte do Estado de São Paulo. Dissertação de Mestrado, Universidade Estadual Paulista, Botucatu, 126 pp.

Meireles AL, R Biagi \& FLM Mantelatto. 2003. Hermit crabs in evidence: unusual gastropod shell occupation. Nauplius 11(1): 63-66.

Melo GAS. 1999. Manual de identificação dos Crustacea Decapoda do litoral brasileiro: Anomura, Thalassinidea, Palinuridea, Astacidea, Ed. Pleiade, São Paulo, Brasil, 551 pp. 
Negreiros-Fransozo ML, A Fransozo \& NJ Hebling. 1991. Estrutura populacional e determinação do tamanho da concha ocupada por 4 espécies de ermitões (Crustacea, Decapoda, Anomura) do litoral de São Paulo. Biotemas 4(2): $135-148$.

Negreiros-Fransozo ML, A Fransozo, FLM Mantelatto, MAA Pinheiro \& S Santos. 1997. Anomuran species (Crustacea, Decapoda) and their ecological distribution of Fortaleza Bay sublittoral, Ubatuba, São Paulo, Brazil. Ilheringia, Série Zoologia (83): 187-194.

Osorno JL, L Fernandez-Casillas \& C Rodriguez-Juarez. 1998. Are hermit crabs looking for light and large shell?: Evidence from natural and field induced shell exchanges. Journal of Experimental Marine Biology and Ecology 222: 163-173.

Peres LA. 2005. Aspectos bioecológicos do ermitão Loxopagurus loxochelis (Moreira, 1901) (Anomura, Diogenidae) em duas áreas do Litoral Norte de São Paulo, Brasil. Dissertação de Mestrado, Universidade de São Paulo, Ribeirão Preto, 150 pp.

Pinheiro MAA, A Fransozo \& ML Negreiros-Fransozo. 1993. Seleção e relação com a concha em Isocheles sawayai Forest \& Saint Laurent, 1967 (Crustacea, Anomura, Diogenidae). Arquivos de Biologia e Tecnologia do Paraná 36(4): 745-752.

Pinheiro MAA, A Fransozo \& ML Negreiros-Fransozo. 1996. Distribution patterns of Arenaeus cribrarius (Lamarck, 1818) (Crustacea, Portunidae) in Fortaleza Bay, Ubatuba (SP), Brazil. Revista Brasileira de Biologia 56(4): 705-716.

Pita JB, E Severino-Rodriguez, R Graça-Lopes \& JAP Coelho. 1985. Levantamento da Família Portunidae (Crustacea, Decapoda, Brachyura) no Complexo BaíaEstuário de Santos, São Paulo, Brasil. Boletim do Instituto de Pesca 12(3): 153-162.
Reese ES. 1969. Behavioral adaptations of intertidal hermit crabs. American Zoology 9: 343-355.

Reigada ALD \& S Santos. 1997. Biologia e relação com a concha em Clibanarius vittatus (Bosc, 1802) (Crustacea, Diogenidae) em São Vicente, SP, Brasil. Arquivos de Biologia e Tecnologia do Paraná 40(4): 941-952.

Rios E. 1994. Sea Shells of Brazil. Ed. da FURG, Rio Grande, $344 \mathrm{pp}$.

Sant'Anna BS, CM Zangrande \& ALD Reigada. 2005. Utilization of shells of the snail Achatina fulica Bowdich, 1822 (Mollusca, Gastropoda) by the hermit crab Clibanarius vittatus (Bosc, 1802) (Decapoda, Anomura) in the São Vicente Estuary, São Paulo, Brazil. Investigaciones Marinas 33(2): 217-219.

Santos S, PJ Rieger, RRR Vieira \& RA Barutot. 2000. Composição e distribuição dos Crustacea (Decapoda) na Lagoa do Peixe, Rio Grande do Sul, Brasil. Revista Brasileira Zoologia 17(1): 213-223.

Sokal RR \& FJ Rohlf. 1995. Biometry. Ed. Freeman, New York, 887 pp.

Taissoun E. 1930. Las especies de cangrejos del género “Callinectes” (Brachyura) em el Golfo de Venezuela y Lago de Maracaibo. Boletin del Centro de Investigaciones Biológicas 2: 1-102.

Turra A \& FPP Leite. 2002. Shell utilization patterns of a tropical intertidal hermit crab assemblage. Journal of the Marine Biological Association UK 82: 97-107.

Vernberg FJ \& WB Vernberg. 1970. Lethal limits and zoogeography of the faunal assemblages of coastal Carolina waters. Marine Biology 6: 26-32.

Zangrande CM, BS Sant'Anna \& ALD Reigada. 2003. Distribuição de Arenaeus cribrarius (Lamarck, 1818) no Complexo Baía-Estuário de São Vicente (SP) Brasil, Boletim do Instituto de Pesca 29(2): 133-138. 